\title{
Elevated-Temperature Mechanical Properties of Silicon Nitride/Boron Nitride Fibrous Monolithic Ceramics
}

\author{
Rodney W. Trice ${ }^{* \dagger}$ and John W. Halloran* \\ Materials Science and Engineering Department, University of Michigan, Ann Arbor, Michigan 48109-2136
}

\begin{abstract}
A unique, all-ceramic material capable of nonbrittle fracture via crack deflection and delamination has been mechanically characterized from $25^{\circ}$ through $1400^{\circ} \mathrm{C}$. This material, fibrous monoliths, was comprised of unidirectionally aligned $250 \mu \mathrm{m}$ diameter silicon nitride cells surrounded by 10 to $20 \mu \mathrm{m}$ thick boron nitride cell boundaries. The average flexure strengths of fibrous monoliths were 510 and 290 MPa for specimens tested at room temperature and $1300^{\circ} \mathrm{C}$, respectively. Crack deflection in the BN cell boundaries was observed at all temperatures. Characteristic flexural responses were observed at temperatures between $25^{\circ}$ and $1400^{\circ} \mathrm{C}$. Changes in the flexural response at different temperatures were attributed to changes in the physical properties of either the silicon nitride cells or boron nitride cell boundary.
\end{abstract}

\section{Introduction}

$\mathrm{T}$ HE unique flexural response of fibrous monoliths is a result of the submillimeter architecture engineered into the material, consisting of a hexagonal arrangement of strong cells surrounded by weak cell boundaries. ${ }^{1-5}$ Fibrous monoliths are similar to layered ceramics ${ }^{6}$ in that they consist of an array of weak and strong constituents designed to deflect cracks propagating normal to interfaces. Research on these novel ceramic materials has taken two paths. The first path focuses on the mechanism of crack deflection and delamination and the parameters that influence the degree to which they occur. ${ }^{7-10}$ The second path of research focuses on optimizing their mechanical properties through processing improvements. ${ }^{1,12}$

Until now, only minimal mechanical testing has been performed above room temperature on fibrous monolith ceramics or layered materials. ${ }^{3,5,13}$ As these materials are intended for use in elevatedtemperature applications, their properties must be characterized and understood in environments representative of actual use. As such, the following paper describes research performed in order to develop an understanding of the high-temperature behavior of $\mathrm{Si}_{3} \mathrm{~N}_{4} / \mathrm{BN}$ fibrous monoliths. The fibrous monolith composition studied had silicon nitride cells composed of $92 \mathrm{wt} \% \mathrm{Si}_{3} \mathrm{~N}_{4}, 6 \mathrm{wt} \%$ $\mathrm{Y}_{2} \mathrm{O}_{3}$, and $2 \mathrm{wt} \% \mathrm{Al}_{2} \mathrm{O}_{3}$, with cell boundaries of polycrystalline $\mathrm{BN}$ (referred to as 6Y/2Al-FM). Property comparisons will be made with monolithic silicon nitride with identical sintering aids (referred to as 6Y/2Al-M).

Silicon nitride, the cell material, has been well characterized at high temperatures. Silicon nitride fabricated with sintering aids is essentially a two-phase material in which individual grains of

F.W. Zok-contributing editor

\footnotetext{
Manuscript No. 190141. Received May 29, 1998; approved August 9, 1999.

Based in part on the dissertation submitted by R. W. Trice for the Ph.D. degree in materials science and engineering, The University of Michigan, Ann Arbor, MI, 1997. Supported by DARPA/ONR under Contract No. N0014-95-0302.

${ }^{*}$ Member, American Ceramic Society.

${ }^{\dagger}$ Now at the Department of Materials Science and Engineering, Northwestern University, Evanston, Illinois 60208-0302.
}

silicon nitride are surrounded by an amorphous phase ${ }^{14,15}$ formed from the sintering aid oxides and silica that previously existed on the surface of the silicon nitride powder. Property changes associated with increasing temperature, such as creep resistance and flexure strength, are attributed to changes in this ubiquitous amorphous phase. ${ }^{16-18}$ Neither the ambient- nor elevatedtemperature properties of boron nitride have been well characterized. ${ }^{19,20}$ Furthermore, we know from previous research ${ }^{21}$ that some of the glassy phase from nearby $\mathrm{Si}_{3} \mathrm{~N}_{4}$ cells migrates into the boron nitride cell boundary during hot pressing.

\section{Experimental Procedure}

\section{(1) Materials and Fabrication}

The fabrication methods for producing fibrous monoliths have been described in detail elsewhere. ${ }^{2,5,11,21,22}$ The cell material was prepared from silicon nitride (SN-E-10, Ube Industries) with 6 wt $\% \mathrm{Y}_{2} \mathrm{O}_{3}$ (Reaction, 99.9\% Pure, Johnson Matthey) and $2 \mathrm{wt} \%$ $\mathrm{Al}_{2} \mathrm{O}_{3}$ (RC-HP DBM, Malakoff Industries) added as sintering aids. Hexagonal boron nitride (Advanced Ceramics, HCP), consisting of platelike particles 7 to $10 \mu \mathrm{m}$ in diameter and 0.1 to $0.3 \mu \mathrm{m}$ thick, was used to fabricate the cell boundaries. Filaments, consisting of a core of silicon nitride/polymer additives and an outer layer of $\mathrm{BN} /$ polymer additives, were melt extruded to a diameter of 250 $\mu \mathrm{m}$. A filament winding approach, developed by King, ${ }^{12}$ was used to fabricate $\mathrm{Si}_{3} \mathrm{~N}_{4} / \mathrm{BN}$ fibrous monoliths with uniaxially aligned cells.

Monolithic silicon nitride billets were prepared ${ }^{23}$ by cutting small pieces of a silicon nitride/polymer mixture and warm pressing them in a rectangular die into $8-9 \mathrm{~mm}$ thick green billets. Sintering aids identical to those in the fibrous monolith cells were used to fabricate the monolithic silicon nitride billet.

Binder burnout of 6Y/2Al-FM and 6Y/2Al-M billets occurred in a tube-furnace slowly heated to $700^{\circ} \mathrm{C}$ in flowing nitrogen. A postbinder burnout heat treatment was conducted in flowing air through $400^{\circ} \mathrm{C}$ to remove residual carbon. Billets were hot-pressed in a graphite die at $1740^{\circ} \mathrm{C}$, under an applied pressure of $25 \mathrm{MPa}$ for $2 \mathrm{~h}$. The heating rate was approximately $600^{\circ} \mathrm{C} / \mathrm{h}$, and load was not applied until the temperature of the surface of the die reached $1200^{\circ} \mathrm{C}$.

\section{(2) Specimen Fabrication and Testing}

The 4 to $4.5 \mathrm{~mm}$ thick densified billets were machined to a thickness of $3 \mathrm{~mm}$ by removing equal amounts of material from both sides. Samples were cut from these billets into $3 \mathrm{~mm} \times 4$ $\mathrm{mm} \times 48 \mathrm{~mm}$ flexure bars with the tensile surface polished through $3 \mu \mathrm{m}$ prior to testing.

The density of $6 \mathrm{Y} / 2 \mathrm{Al}-\mathrm{FM}$ and $6 \mathrm{Y} / 2 \mathrm{Al}-\mathrm{M}$ samples, measured using the Archimedes method, ${ }^{24}$ was determined to be $3.07 \pm 0.01$ and $3.27 \pm 0.01 \mathrm{~g} / \mathrm{cm}^{3}$, respectively. The average measured densities (based on $80 \mathrm{vol} \% \mathrm{Si}_{3} \mathrm{~N}_{4}$ cells and $20 \mathrm{vol} \% \mathrm{BN}$ cell boundaries for fibrous monoliths) were slightly above theoretical calculated values. $\mathrm{Cu} K \alpha \mathrm{X}$-ray diffraction of pulverized specimens indicated complete transformation of the starting $\alpha-\mathrm{Si}_{3} \mathrm{~N}_{4}$ powder to $\beta-\mathrm{Si}_{3} \mathrm{~N}_{4}$. 
Flexure testing ${ }^{25}$ was performed on a screw-driven load frame (Instron 4483, Instron Corp., Canton, MA) equipped with a $5 \mathrm{kN}$ load cell and a clamshell furnace (Applied Test Systems, Butler, PA). Material evaluations were made between $25^{\circ}$ and $1400^{\circ} \mathrm{C}$ in air, employing a $10 \mathrm{~min}$ dwell before testing. Five or more specimens were tested at $25^{\circ}$ and $1000^{\circ} \mathrm{C}$, while three replicates each were performed on samples tested at $600^{\circ}, 800^{\circ}, 1100^{\circ}$, $1200^{\circ}$, and $1300^{\circ} \mathrm{C}$. Only one specimen was tested at $1400^{\circ} \mathrm{C}$. A thermocouple was placed within $5 \mathrm{~mm}$ of the sample, near the midspan, during testing. A silicon carbide 4-point fixture, with outer and inner spans fixed at 40 and $20 \mathrm{~mm}$, respectively, was used for all tests. All flexural tests were conducted at a crosshead rate of $0.5 \mathrm{~mm} / \mathrm{min}$. The load versus crosshead deflection response and the work of fracture, calculated by determining the area under the load-crosshead deflection curve and dividing it by twice the cross-sectional area of the sample, are reported. The "apparent stress" was calculated using the standard beam equation for bending, ${ }^{25}$ employing the original cross-sectional area even after the initial failure event.

The flexural modulus was determined as a function of temperature from $25^{\circ}$ through $1300^{\circ} \mathrm{C}$ using the elastic beam equation for samples loaded in 4-point bending. The stiffness of the load frame was determined between $25^{\circ}$ and $1300^{\circ} \mathrm{C}$ using a standard material (Hexalloy $\mathrm{SiC}$ ) with known modulus as a function of temperature. The loading regime where modulus measured was 0 through 150 $\mathrm{MPa}$. The cumulative error associated with modulus measurements was approximately $\pm 6 \%$.

\section{Results and Discussion}

\section{(1) Elastic Properties of 6Y/2Al-FMs and 6Y/2Al-Ms versus Temperature}

Figure 1 presents the flexural modulus of $6 \mathrm{Y} / 2 \mathrm{Al}-\mathrm{FM}$ and $6 \mathrm{Y} / 2 \mathrm{Al}-\mathrm{M}$ specimens as a function of temperature. At room temperature, the modulus of $6 \mathrm{Y} / 2 \mathrm{Al}-\mathrm{FM}$ was $279 \mathrm{GPa}$, with a drop in the modulus observed from $274 \mathrm{GPa}$ to $233 \mathrm{GPa}$ between $900^{\circ}$ and $1000^{\circ} \mathrm{C}$. The modulus decreased further through $1300^{\circ} \mathrm{C}$; however, linear elastic behavior was observed through the peak strength at this temperature. The modulus was not determined at $1400^{\circ} \mathrm{C}$ because nonlinear stress-deflection behavior was observed at stresses as low as $65 \mathrm{MPa}$. The temperature dependence of the modulus of 6Y/2Al-M closely followed the trends of $6 \mathrm{Y} / 2 \mathrm{Al}-\mathrm{FM}$, with its modulus typically $15 \%$ greater than that measured for the fibrous monolith samples.

Previous research has suggested that the reduction in modulus of monolithic silicon nitride as temperature is increased is a result of the viscosity reduction of the glassy phase that surrounds the silicon nitride grains. ${ }^{26}$ The decrease in modulus over this narrow temperature range $\left(900^{\circ}\right.$ to $\left.1000^{\circ} \mathrm{C}\right)$ is consistent with literature values for $T_{\mathrm{g}}$ of this glassy phase composition. ${ }^{26}$ As the results

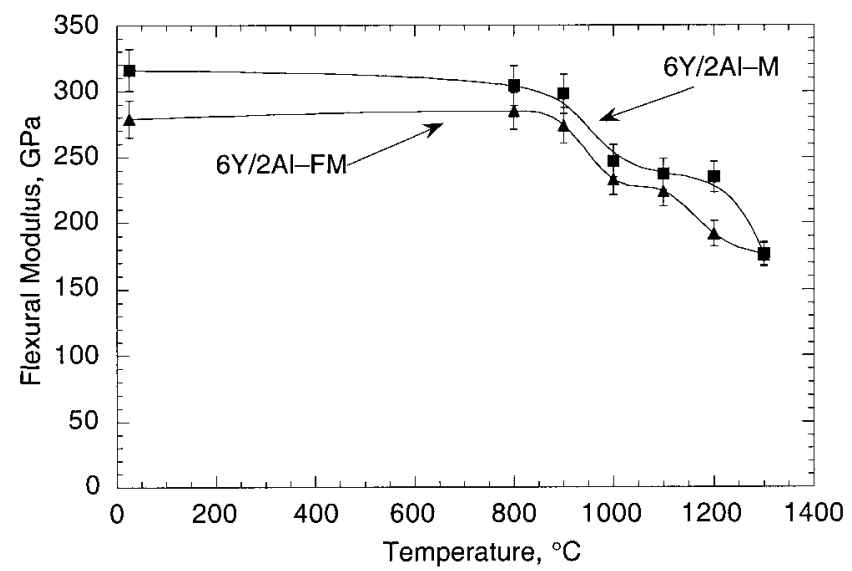

Fig. 1. Plot of flexural modulus versus temperature for $6 \mathrm{Y} / 2 \mathrm{Al}-\mathrm{FM}$ and 6Y/2Al-M specimens.

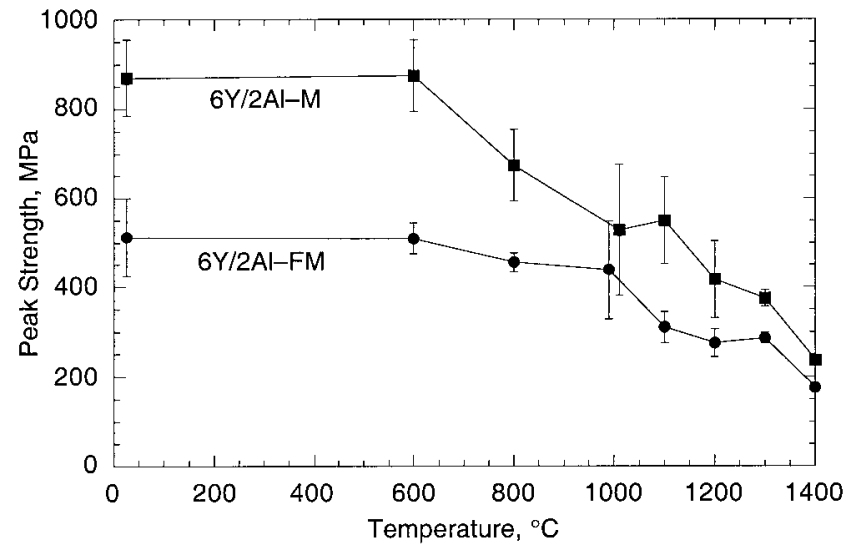

Fig. 2. Comparison of flexure strengths of fibrous monolith and monolithic specimens with $6 \mathrm{wt} \% \mathrm{Y}_{2} \mathrm{O}_{3}$ and $2 \mathrm{wt} \% \mathrm{Al}_{2} \mathrm{O}_{3}$ sintering additives. The results at $1000^{\circ} \mathrm{C}$ have been offset slightly for clarity.

indicate that there is a close matching of shifts in the monolithic and fibrous monolith flexural modulus curves, changes in the glassy phase seem to govern the high-temperature elastic properties of fibrous monoliths as well.

\section{(2) Fibrous Monolith and Monolithic Flexure Strengths}

Figure 2 presents an overview of the flexure results for $6 \mathrm{Y} / 2 \mathrm{Al}-\mathrm{M}$ and 6Y/2Al-FMs as a function of temperature. The $6 \mathrm{Y} / 2 \mathrm{Al}-\mathrm{M}$ fracture strengths varied from an average of $870 \mathrm{MPa}$ at ambient temperatures to $236 \mathrm{MPa}$ at $1400^{\circ} \mathrm{C}$, with failure always initiating on the tensile surface. Typical standard deviations were on the order of $80 \mathrm{MPa}$, with the exception of samples tested at $1000^{\circ} \mathrm{C}$. At this temperature, peak strengths ranged from 400 to $800 \mathrm{MPa}$, resulting in a standard deviation of $148 \mathrm{MPa}$. The observed trends compare well with published results for monolithic silicon nitride. ${ }^{18}$

The fibrous monolith peak strengths ranged from a mean of 512 $\mathrm{MPa}$ at room temperature to $176 \mathrm{MPa}$ at $1400^{\circ} \mathrm{C}$. Greater scatter was observed in the $1000^{\circ} \mathrm{C}$ data, similar to the monolithic behavior. Furthermore, the flexure strength plateaus at approximately $290 \mathrm{MPa}$ for specimens tested at $1100^{\circ}$ through $1300^{\circ} \mathrm{C}$. Overall, specimens remained linear elastic up to the peak strength for temperatures as high as $1300^{\circ} \mathrm{C}$.

The strengths between $25^{\circ}$ and $600^{\circ} \mathrm{C}$ remained constant for both the fibrous monolith and monolithic samples. Beyond $600^{\circ} \mathrm{C}$, the strengths of fibrous monolith samples were statistically the same through $1000^{\circ} \mathrm{C}$, unlike what was observed for monolithic silicon nitride specimens. As discussed previously, the presence of glassy phase in the boron nitride cell boundaries strongly suggests that less glassy phase is present in the silicon nitride grains within the cells of fibrous monoliths as compared to silicon nitride grains in a monolithic specimen. Thus, the difference in strength trends through $1000^{\circ} \mathrm{C}$ between the monolithic and fibrous monolith materials may be explained by the different amounts of glassy phase in the silicon nitride of the two materials. However, we must also remember that fibrous monoliths are not governed by weaklink statistics, unlike monolithic materials. For example, a few cells of a fibrous monolith can fracture without catastrophic failure occurring if the remaining cells can support the applied stress. This is the case at $1000^{\circ} \mathrm{C}$, as shown in Fig. 3, where a few cells have fractured (near $400 \mathrm{MPa}$ ) before the peak stress is reached (500 $\mathrm{MPa}$ ). Thus, architectural design of fibrous monolith may also contribute to the observed strength trends through $1000^{\circ} \mathrm{C}$.

\section{(3) Overview of Temperature Dependence on Properties of FMs}

Figure 3 reveals the flexural response of $6 \mathrm{Y} / 2 \mathrm{Al}-\mathrm{FMs}$ as a function of temperature. In general, the jagged nature of the apparent stress versus deflection curves is an indication of the number of crack deflection events occurring, with each apparent 


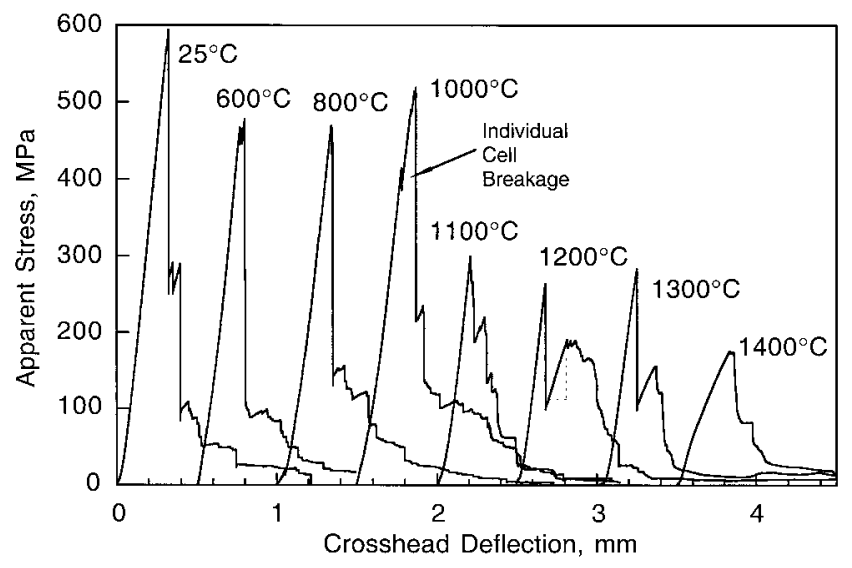

Fig. 3. Typical characteristic apparent stress versus crosshead deflection curves as a function of temperature for $6 \mathrm{Y} / 2 \mathrm{Al}-\mathrm{FMs}$.

stress peak and subsequent drop related to tensile crack initiation in the silicon nitride and crack deflection and delamination in the boron nitride interphase. Like specimens tested at ambient temperatures, specimens tested at elevated temperatures exhibited noncatastrophic failure by retaining significant load-carrying ability after the maximum strength was achieved.

Three different failure modes were observed in fibrous monoliths at elevated temperatures: (1) tensile initiated failure in the outer-ply silicon nitride cells $\left(25^{\circ}\right.$ to $\left.1000^{\circ} \mathrm{C}\right)$, (2) shear-initiated failure at the beam midplane in the boron nitride $\left(1100^{\circ}\right.$ to $1300^{\circ} \mathrm{C}$ ), and (3) viscoelastic flow of the silicon nitride on the tensile surface $\left(1400^{\circ} \mathrm{C}\right)$. These changes in flexural response and failure mode will be discussed in the following subsections.

(A) 6Y/2Al-FM Response between $25^{\circ}$ and $1000^{\circ} \mathrm{C}$ : All fibrous monolith samples tested between $25^{\circ}$ and $1000^{\circ} \mathrm{C}$ exhibited tensile initiated failure on the outer ply of the sample. The stress-displacement behavior of $6 \mathrm{Y} / 2 \mathrm{Al}-\mathrm{FMs}$ at $25^{\circ}, 600^{\circ}, 800^{\circ}$, and $1000^{\circ} \mathrm{C}$ exhibit similar strength; however, the failure behavior changes dramatically at $1000^{\circ} \mathrm{C}$.

Inspection of Figs. 4(a) and (b), sideviews of flexure samples tested at $25^{\circ}$ and $1000^{\circ} \mathrm{C}$, respectively, reveal much different fracture behavior. At $25^{\circ} \mathrm{C}$, the presence of one long delamination crack is observed, followed by many short deflected cracks as the original tensile initiated crack works its way from the tensile surface through the thickness of the sample. At $1000^{\circ} \mathrm{C}$, almost every layer deflects the tensile initiated crack down the interphase of boron nitride, resulting in long delamination distances. A consequence of this behavior is a very "woodlike" fracture. The change in the crack deflection and delamination behavior of $6 \mathrm{Y} / 2 \mathrm{Al}-\mathrm{FMs}$ at $1000^{\circ} \mathrm{C}$ is likely a result of the changing interfacial fracture energy, as concurrent research ${ }^{21}$ reveals a large increase in $\Gamma_{\mathrm{BN}}$ at this temperature. This increase was shown to be a result of softening of the glassy phase residing in the BN cell boundary.

Cutler et $a .^{27}$ have observed a threefold increase in the interfacial fracture energy for a glassy matrix heated to its strain point. Beyond this temperature (beginning at the annealing point of the glass), a change in failure mode was observed from matrix cracking to a process of cavitation and rupture. In the current research, the change in failure behavior occurs where $\Gamma_{\mathrm{BN}}$ peaks rather than after the peak as observed by Cutler. However, common to both material systems is that a change in failure is observed due to a change in the properties of the glassy phase.

(B) $6 \mathrm{Y} / 2 \mathrm{Al}-\mathrm{FM}$ Response between $1100^{\circ}$ and $1300^{\circ} \mathrm{C}$ : $\mathrm{Be}-$ tween $1100^{\circ}$ and $1300^{\circ} \mathrm{C}$, the fibrous monolith strength plateaus at approximately $290 \mathrm{MPa}$ (see Fig. 2). The strength plateau observed in fibrous monoliths is a result of the change in failure mode from tensile initiated on the outer ply of the specimen to shear-initiated failure near the midplane of the sample. The average shear stress to cause failure between $1100^{\circ}$ through $1300^{\circ} \mathrm{C}$ was approximately $23 \mathrm{MPa}$.

Inspection of the failed sample, shown in Fig. 4(c), indicates the presence of a lengthwise horizontal crack that split part of the beam into halves, characteristic of midplane-initiated shear failure. As the shear stress is zero between the two inner loading pins in the 4-point geometry, the shear crack initially began between the two outer loading pins where there is an appreciable shear stress. Beyond the initial shear failure, further loading resulted in tensile initiated failure on one or both of the two split beams, propagating in a manner similar to that observed at $25^{\circ} \mathrm{C}$.

This change in failure mode is also observed in the flexural response at $1200^{\circ} \mathrm{C}$ as shown in Fig. 3. Following the peak strength and subsequent reloading of the specimen, a distinct slope was observed in the apparent stress versus crosshead deflection curve. If a beam is horizontally split into two equal beams, the resulting stiffness of the two beams will be one-quarter the original stiffness of the intact beam. The ratio of stiffness after the first crack to the original stiffness of the specimen, as measured in Fig. 3 , is 0.4 . This is consistent with a horizontal crack that extends about halfway down the beam.

As observed in concurrent research, ${ }^{21}$ transmission electron microscopy of fibrous monoliths indicates that the sintering aid added to the silicon nitride cells has migrated to the boron nitride cell boundaries during hot pressing, with approximately $20 \mathrm{vol} \%$ glass residing in the cell boundary. Softening of the glassy phase in the boron nitride is likely responsible for the change in failure mode from tensile initiation to shear initiation in bars tested at $1100^{\circ}$ to $1300^{\circ} \mathrm{C}$. In general, this failure mode was more pronounced in samples tested at $1200^{\circ}$ and $1300^{\circ} \mathrm{C}$.

This hypothesis was investigated by conducting SEM investigations on the sheared failure surface of specimens tested between $1100^{\circ}$ and $1300^{\circ} \mathrm{C}$. Figure 5 is an SEM micrograph of the shear failure surface for a specimen tested at $1100^{\circ} \mathrm{C}$. Boron nitride was observed on both sides of the failure surface indicating that the crack propagated within the boron nitride cell boundary, rather than at the $\mathrm{Si}_{3} \mathrm{~N}_{4}-\mathrm{BN}$ interface. The features lying above the fracture surface are basal plane oriented boron nitride platelets that have been peeled up during deformation. Observation of the shear surfaces revealed the presence of several small glass globules, approximately $0.5 \mu \mathrm{m}$ in diameter. EDS indicates the presence of yttrium, silicon, aluminum, oxygen, and nitrogen in the globules, consistent with the composition of the glassy phase that exists between grains of silicon nitride in cell regions. ${ }^{21}$ A similar fracture surface was observed for specimens tested at $1200^{\circ}$ and $1300^{\circ} \mathrm{C}$. Further, the high contact angle and spherical shape of the globules seem to indicate that the cell boundary glassy phase was softened at these temperatures. Thus, the presence of glassy phase on the surface along with the fact that it was clearly softened at the testing temperature are consistent with reductions in the viscosity of the glassy phase controlling the high-temperature failure of fibrous monoliths.

(C) $6 Y / 2 \mathrm{Al}-\mathrm{FM}$ Response at $1400^{\circ} \mathrm{C}$ : The viscoelastic flow properties of the silicon nitride cells dominate behavior of fibrous monolithic ceramics at $1400^{\circ} \mathrm{C}$. Tensile initiation, rather than shear cracking at the midplane, was observed in specimens tested at this temperature. Visual inspection of Fig. 4(d) of the test bar indicated an appreciable bend in the silicon nitride cells in the area under the maximum bending moment. This phenomenon is consistent with the easy flow of the grain boundary glassy phase present in the silicon nitride cells as was observed in creep tests of a similar composition silicon nitride at this temperature. ${ }^{28}$ Crack deflection and delamination were also observed at this temperature. Not all of what appeared to be long delamination cracks were actually cracks, as microscopic investigation of the boron nitride cell boundaries revealed significant oxidation, leaving empty channels between the silicon nitride cells.

\section{(4) Crack Delamination as a Function of Temperature in 6Y/2Al-FMs}

Crack deflection alone is not enough to achieve high-energy absorption in fibrous monoliths during flexure failure. Crack delamination, the case when the deflected crack runs a significant distance down the interphase, is highly desired as it increases the amount of energy the beam can absorb during failure. 
(a)

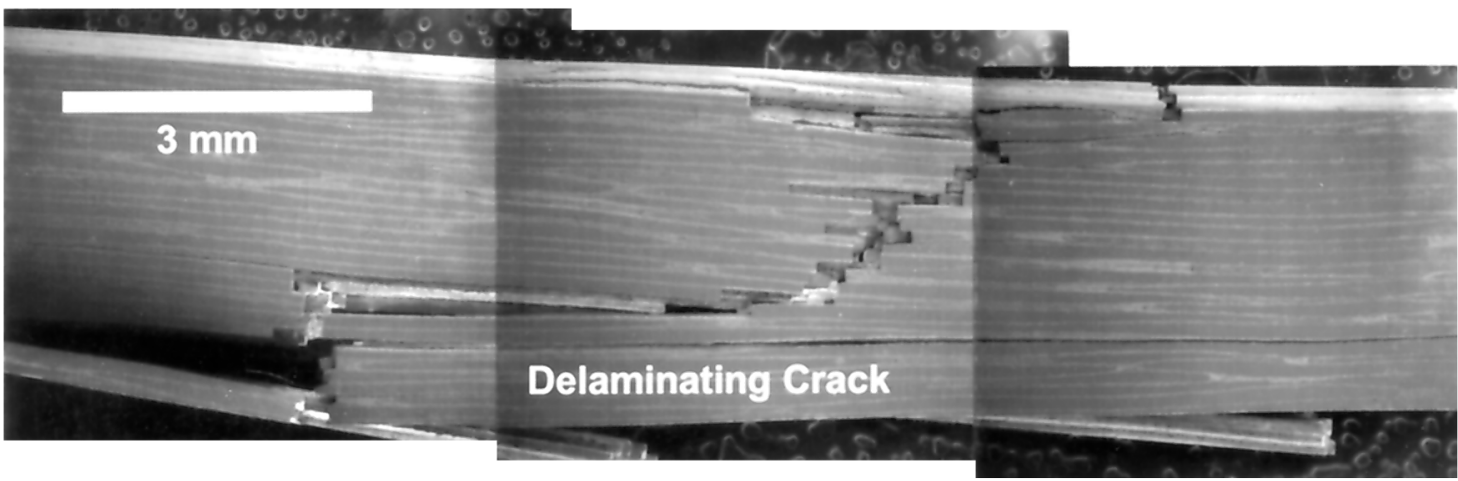

(b)

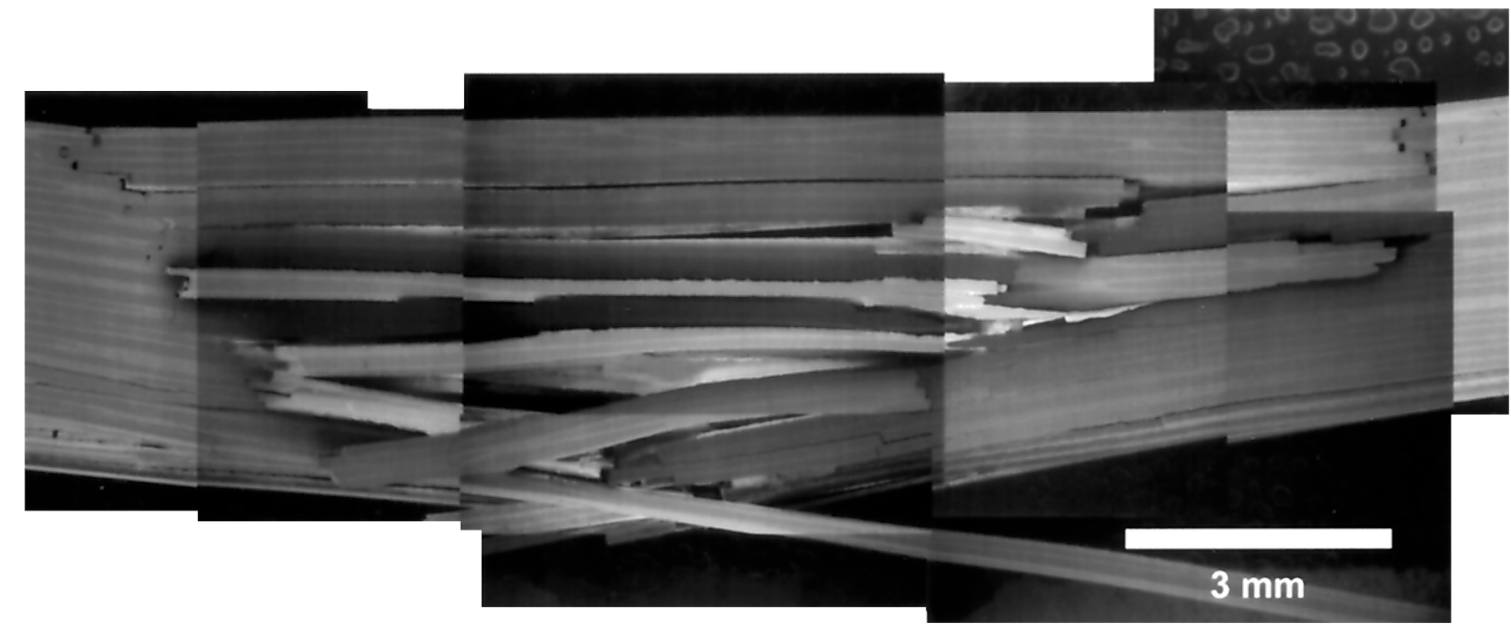

(c)

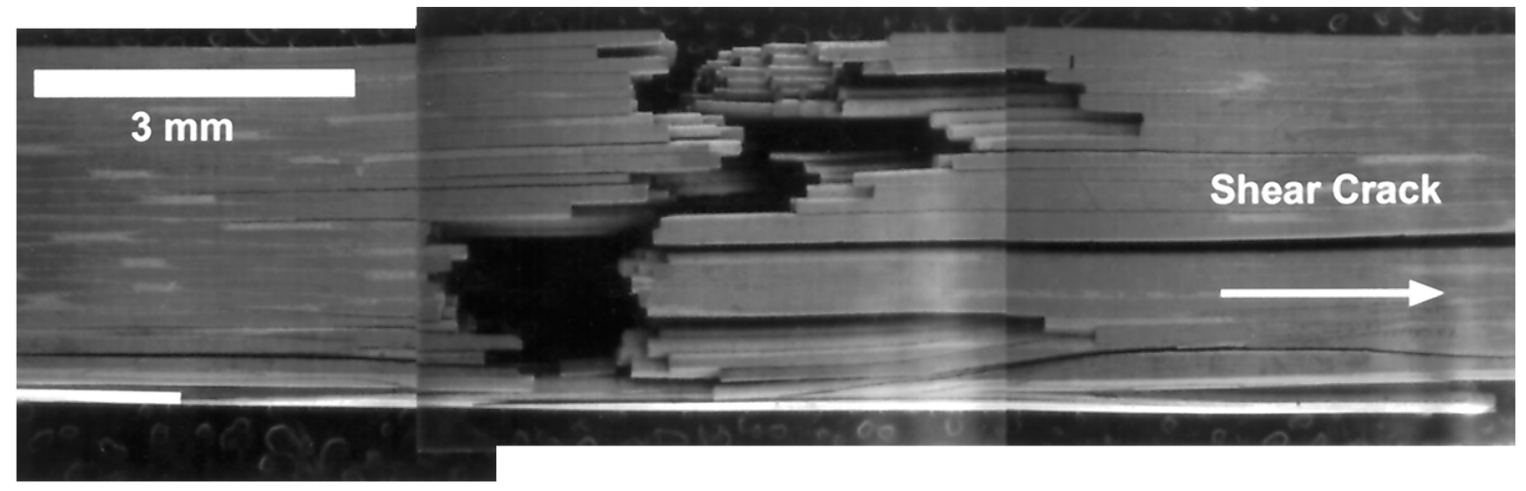

(d)

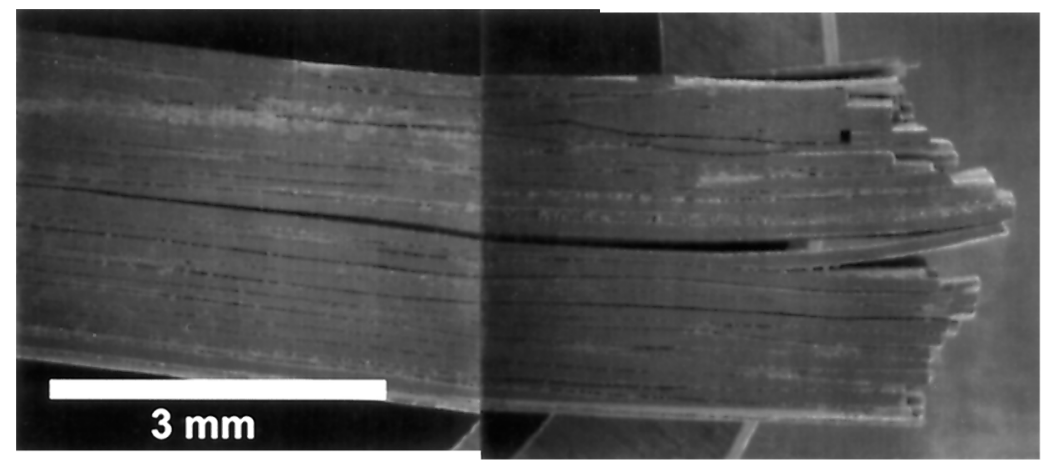

Fig. 4. Side view of tested flexure samples at (a) $25^{\circ}$, (b) $1000^{\circ}$, (c) $1200^{\circ}$, and (d) $1400^{\circ} \mathrm{C}$. At $1000^{\circ} \mathrm{C}$ extensive delamination was observed at almost every layer. At $1200^{\circ} \mathrm{C}$, a long horizontal crack formed initially between one of the outer and inner loading pins due to shear stresses. At $1400^{\circ} \mathrm{C}$, appreciable plastic flow was observed during failure. 

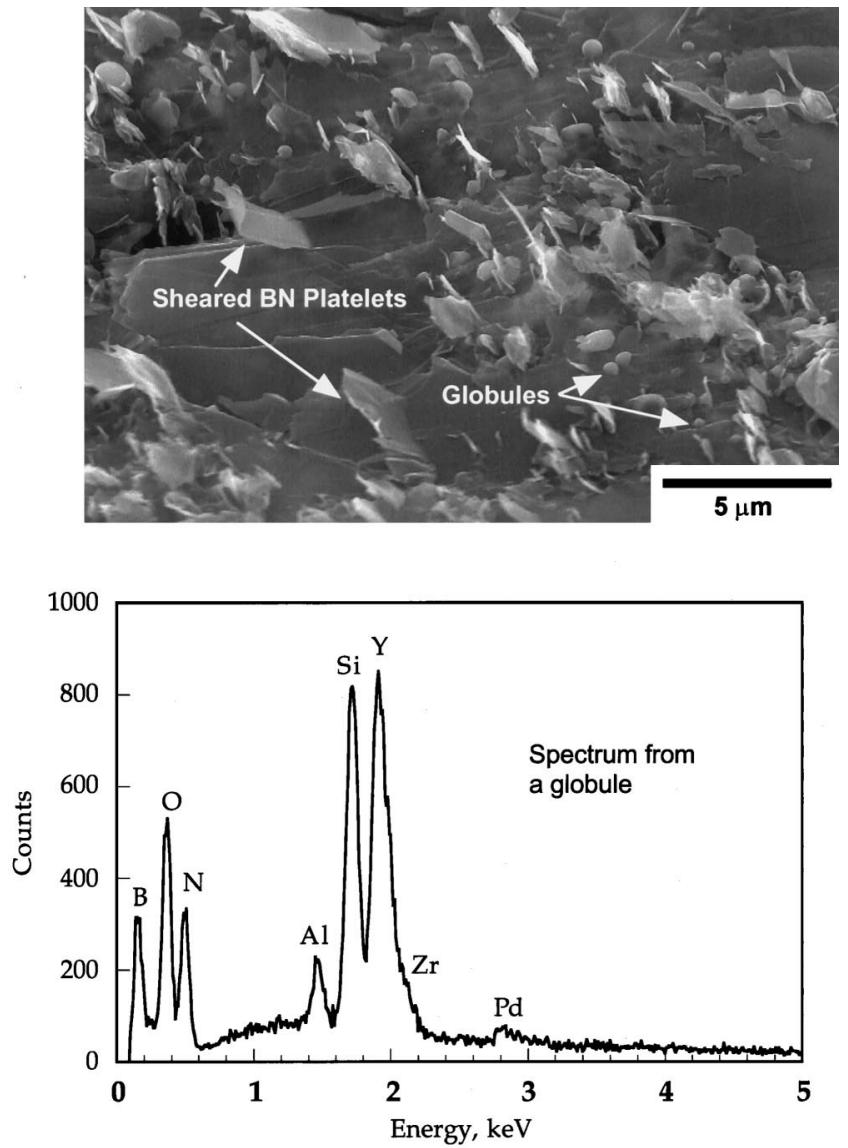

Fig. 5. SEM micrograph of the shear surface of a fibrous monolith tested at $1100^{\circ} \mathrm{C}$. Both sheared boron nitride platelets and globules of an amorphous phase were observed. EDS results of a globule indicated that it contained yttrium, silicon, oxygen, nitrogen, and aluminum. It is unclear because of the small globule size whether boron is detected in the globules or is from the surrounding boron nitride grains. Zirconium presence is traced to milling media contamination while palladium is an artifact of preparation.

Kovar et al. ${ }^{9}$ have investigated the importance of the $\Gamma_{\mathrm{BN}} / \Gamma_{\mathrm{SN}}$ ratio in determining whether a crack, once it is deflected into the interphase, will continue to propagate within the plane of the interphase. They observed that increasing the ratio $\Gamma_{\mathrm{BN}} / \Gamma_{\mathrm{SN}}$ minimally affected the amount of crack deflection but significantly decreased the delamination distance after crack deflection. They also observed that the amount of delamination strongly affected the work of fracture.

By plotting the ratio of the fracture energies of the boron nitride $^{21}$ and the silicon nitride ${ }^{23}$ (see Table I) along with the average work of fracture from fibrous monoliths tested presently, it can be discerned whether trends observed at room temperature by Kovar et al. ${ }^{9}$ are also observed at elevated temperatures. The results are plotted in Fig. 6. From the figure, it is clear that both the $1300^{\circ}$ and $1000^{\circ} \mathrm{C}$ test results do not follow the expected trends.

Table I. Tabulated Values of Work of Fracture, $\Gamma_{\mathrm{BN}}{ }^{21}$ and $\Gamma_{\mathrm{SN}}^{23}$ Used in Figure 6

\begin{tabular}{cccc}
\hline $\begin{array}{c}\text { Temperature } \\
\left({ }^{\circ} \mathrm{C}\right)\end{array}$ & $\begin{array}{c}\text { Work of fracture } \\
\left(\mathrm{J} / \mathrm{m}^{2}\right)\end{array}$ & $\begin{array}{c}\Gamma_{\mathrm{BN}} \\
\left(\mathrm{J} / \mathrm{m}^{2}\right)\end{array}$ & $\begin{array}{c}\Gamma_{\mathrm{SN}} \\
\left(\mathrm{J} / \mathrm{m}^{2}\right)\end{array}$ \\
\hline 25 & $7400 \pm 1400$ & $37.0 \pm 3.2$ & $129 \pm 9$ \\
800 & $5600 \pm 1000$ & $36.4 \pm 1.3$ & $100 \pm 5$ \\
1000 & $7800 \pm 2100$ & $56 \pm 5.5$ & $98 \pm 6$ \\
1100 & $3400 \pm 400$ & $36.8 \pm 2.5$ & $97 \pm 14$ \\
1200 & $4900 \pm 600$ & $17.6 \pm 0.3$ & $65 \pm 15$ \\
1300 & $3200 \pm 500$ & $19.5 \pm 4.0$ & $387 \pm 148$ \\
\hline
\end{tabular}

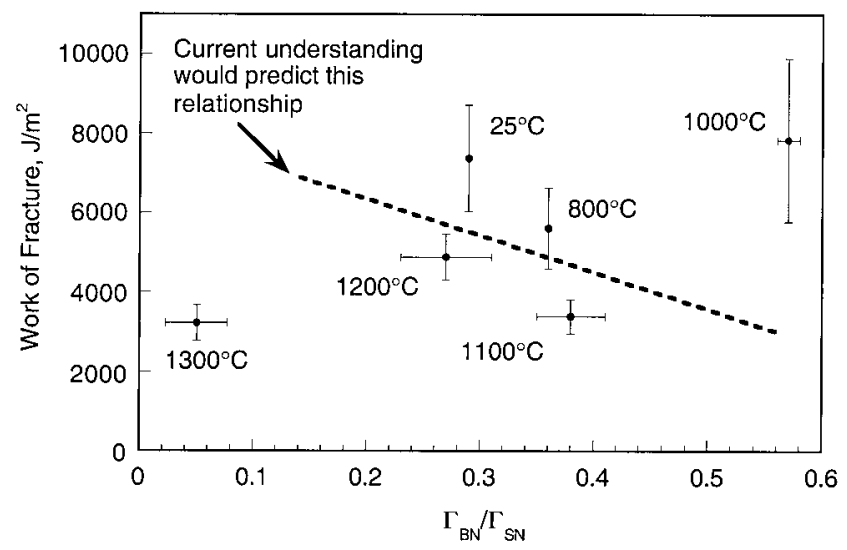

Fig. 6. Plot of $\Gamma_{\mathrm{BN}} / \Gamma_{\mathrm{SN}}$ versus the work of fracture for the present data along with the trends observed by Kovar et al. ${ }^{9}$

At $1300^{\circ} \mathrm{C}$, oxidation of the $\mathrm{BN}$ interphase may influence the results. However, the results at $1000^{\circ} \mathrm{C}$ are clearly in conflict with the current understanding of the parameters that govern crack delamination. The relatively high $\Gamma_{\mathrm{BN}} / \Gamma_{\mathrm{SN}}$ ratio would predict very short delamination cracks and, consequently, low work of fractures. This was not the case at this temperature, where very long delamination distances and woodlike fractures were observed (see Fig. 4(b)).

It is unclear why long delamination cracks are observed when the ratio $\Gamma_{\mathrm{BN}} / \Gamma_{\mathrm{SN}}$ is highest. Kovar et al. ${ }^{9}$ have suggested that there may exist an optimum $\Gamma_{\mathrm{BN}} / \Gamma_{\mathrm{SN}}$ ratio for the $\mathrm{Si}_{3} \mathrm{~N}_{4} / \mathrm{BN}$ system that maximizes the energy absorption capacity. Above the optimum ratio, short delamination distances are favored. Below this value, the interface is too weak and shear delamination is observed. However, the ratio of $\Gamma_{\mathrm{BN}} / \Gamma_{\mathrm{SN}}$ at $1000^{\circ} \mathrm{C}, 0.56$, is likely to be high based on the results of their work which indicate a ratio of 0.4 for the optimum ratio. Ultimately, the behavior at $1000^{\circ} \mathrm{C}$ is unique in that long delamination cracks result, contrary to previously observed trends at room temperature. Future work should focus on delineating this mechanism, perhaps in a more model system than $\mathrm{BN} / \mathrm{Si}_{3} \mathrm{~N}_{4}$.

\section{Summary and Conclusions}

Elevated-temperature tests were performed on unidirectionally aligned 6Y/2Al-FM ceramics from room temperature through $1400^{\circ} \mathrm{C}$. The elastic properties of fibrous monolith ceramics closely followed the trends of monolithic silicon nitrides as a function of temperature, indicating that the glassy phase formed during hot-pressing each billet controls the high-temperature elastic properties.

Flexure strengths of 6Y/2Al-FMs decreased from $510 \mathrm{MPa}$ for specimens tested at room temperature to $176 \mathrm{MPa}$ at $1400^{\circ} \mathrm{C}$, with crack deflection and delamination being observed at all temperatures. Three distinct failure modes were observed as temperature was increased from ambient temperatures. The changes in failure mode and flexural response were attributed to changes in the physical properties of either the $\mathrm{Si}_{3} \mathrm{~N}_{4}$ cells or BN cell boundary. The initial softening of the $\mathrm{BN}$ interphase glass resulted in a failure characterized by increased delamination distances observed over a narrow temperature range.

\section{References}

${ }^{1}$ S. Baskaran, S. D. Nunn, D. Popovic, and J. W. Halloran, "Fibrous Monolithic Ceramics: I, Fabrication, Microstructure, and Indentation Behavior," J. Am. Ceram. Soc., 76 [9] 2209-16 (1993).

${ }^{2}$ S. Baskaran and J. W. Halloran, "Fibrous Monolithic Ceramics: II, Flexural Strength and Fracture Behavior of the Silicon Carbide/Graphite System," J. Am. Ceram. Soc., 76 [9] 2217-24 (1993). 
${ }^{3}$ S. Baskaran and J. W. Halloran, "Fibrous Monolithic Ceramics: III, Mechanical Properties and Oxidation Behavior of the Silicon Carbide/Boron Nitride System," J. Am. Ceram. Soc., 77 [5] 1249-55 (1994).

${ }^{4}$ S. Baskaran, S. D. Nunn, and J. W. Halloran, "Fibrous Monolithic Ceramics: IV, Mechanical Properties and Oxidation Behavior of the Alumina/Nickel System," J. Am. Ceram. Soc., 77 [5] 1256-62 (1994).

${ }^{5}$ G. Hilmas, A. Brady, U. Abdali, G. Zywicki, and J. Halloran, "Fibrous Monoliths: Nonbrittle Fracture from Powder-Processed Ceramics," Mater. Sci. Eng., A, 195, 263-68 (1995).

${ }^{6}$ W. J. Clegg, K. Kendall, N. McN. Alford, T. W. Button, and J. D. Birchall, "A Simple Way to Make Tough Ceramics," Nature (London), 357 [October 4] 455-57 (1990).

${ }^{7}$ A. J. Phillipps, W. J. Clegg, and T. W. Clyne, "Fracture Behavior of Ceramic Laminates in Bending-I. Modeling of Crack Propagation," Acta Metall., 41 [3] 805-17 (1993).

${ }^{8}$ M.-Y. He and J. W. Hutchinson, "Crack Deflection at an Interface Between Dissimilar Elastic Materials,” Int. J. Solids Struct., 25 [9] 1053-67 (1989).

${ }^{9}$ D. Kovar, M. D. Thouless, and J. W. Halloran, "Crack Deflection and Propagation in Layered Silicon Nitride/Boron Nitride Ceramics," J. Am. Ceram. Soc., 81 [4] 1004-12 (1998).

${ }^{10}$ C. A. Folsom, F. W. Zok, and F. F. Lange, "Flexural Properties of Brittle Multilayer Materials: I, Modeling," J. Am. Ceram. Soc., 77 [3] 689-96 (1994).

${ }^{11}$ D. Kovar, B. H. King, R. W. Trice, and J. W. Halloran, "Fibrous Monolithic Ceramics," J. Am. Ceram. Soc., 80 [10] 2471-87 (1997).

${ }^{12}$ B. H. King and J. W. Halloran, "Fibrous Monolithic Ceramic Laminates I: Properties and Behavior of Unidirectional Laminates," unpublished work.

${ }^{13}$ G. A. Brady, "Silicon Nitride/Boron Nitride Fibrous Monolithic Ceramics"; Master's Thesis. University of Michigan, Ann Arbor, MI, 1996.

${ }^{14}$ D. R. Clarke and G. Thomas, "Grain Boundary in a Hot-Pressed MgO Fluxed Silicon Nitride," J. Am. Ceram. Soc., 60 [11-12] 491-95 (1977).

${ }^{15}$ L. K. V. Lou, T. E. Mitchell, and A. H. Heuer, "Impurity Phases in Hot-Pressed $\mathrm{Si}_{3} \mathrm{~N}_{4}$," J. Am. Ceram. Soc., 61 [9-10] 392-96 (1978).

${ }^{16}$ R. L. Tsai and R. Raj, "Creep Fracture in Ceramics Containing Small Amounts of a Liquid Phase," Acta Metall., 30 1043-58 (1982).
${ }^{17}$ M. D. Thouless, "A Review of Creep Rupture in Materials Containing an Amorphous Phase," Res Mech., 22, 213-42 (1987).

${ }^{18}$ D. E. Wittmer, B. E. Rodely, V. A. Knapp, and S. P. Etherton, "Comparison of Properties for Formulations Prepared from Two Silicon Nitride Powders," Ceram. Eng. Sci. Proc., 17 [3] 363-70 (1996).

${ }^{19}$ A. W. Moore, "Characterization of Pyrolytic Boron Nitride for Semiconductor Materials Processing," J. Cryst. Growth, 106, 6-15 (1990).

${ }^{20}$ N. J. Archer, "The Preparation and Properties of Pyrolitic Boron Nitride," High Temp. Chem. Inorg. Ceram. Mater., Proc. Conf. 1976, 30, 167-80 (1977).

${ }^{21}$ R. W. Trice and J. W. Halloran, "Influence of Microstructure and Temperature on the Interfacial Fracture Energy of Silicon Nitride/Boron Nitride Fibrous Monolithic Ceramics," J. Am. Ceram. Soc., 82 [9] 2502-508 (1999).

${ }^{22}$ G. E. Hilmas, G. A. Brady, and J. W. Halloran, "SiC and $\mathrm{Si}_{3} \mathrm{~N}_{4}$ Fibrous Monoliths: Nonbrittle Fracture from Powder-Processed Ceramics Produced by Coextrusion"; pp. 609-14 in Ceramic Transactions, Vol. 51, Fifth International Conference on Ceramic Processing Science and Technology. Edited by H. Hausner, G. L. Messing, and S.-I. Hirano. American Ceramic Society, Westerville, OH, 1994.

${ }^{23}$ R. W. Trice and J. W. Halloran, "The Mode I Fracture Toughness of a Small-Grained Silicon Nitride: Orientation, Temperature, and Crack Length Effects," J. Am. Ceram. Soc., 82 [10] 2633-40 (1999).

${ }^{24}$ ASTM Standard C 373-72, American Society for Testing and Materials, West Conshohocken, PA, 1982.

${ }^{25}$ MIL-STD-1942, "Flexural Strength of High Performance Ceramics at Ambient Temperatures," November 1990

${ }^{26}$ T. Rouxel, J.-L. Besson, C. Gault, P. Goursat, M. Leigh, and S. Hampshire, "Viscosity and Young's Modulus of an Oxynitride Glass," J. Mater. Sci. Lett., 8, 1158-60 (1989).

${ }^{27}$ W. A. Cutler, F. W. Zok, F. F. Lange, and P. G. Charalambides, "Delamination Resistance of Two Hybrid Ceramic-Composite Laminates," J. Am. Ceram. Soc., 80 [12] 3029-37 (1997).

${ }^{28} \mathrm{~J}$. A. Todd and Z.-Y. Xu, "The High Temperature Creep Deformation of $\mathrm{Si}_{3} \mathrm{~N}_{4}-6 \mathrm{Y}_{2} \mathrm{O}_{3}-2 \mathrm{Al}_{2} \mathrm{O}_{3}$," J. Mater. Sci., 24, 4443-52 (1989). 